\title{
Effects of Photoperiod and Different Artificial Light Colors on Nile Tilapia Growth Rate
}

\author{
Atef Mohamed Elsbaay \\ Department of Agricultural Engineering, Faculty of Agriculture, Kfrelsheikh University, Kafr El-Sheikh 33516 \\ EGYPT
}

\begin{abstract}
Theobjectivesofthepresentstudyweretoexaminetheeffectsofphotoperiodandlight colors on growth rate and activity of Nil Tilapia (Tilapia Niloticus).The fish were fed by hand a commercial feed (crude protein, 27\%; crudelipid $5.06 \%$; crude fiber $5.08 \%$; total energy $4000 \mathrm{kcal} / \mathrm{kg}$ ) for 60 days.The results indicated that photoperiod (24L:OD, 16L:8D and control) and light colors (white, red and blue) were significantly affected fish growth performance. The blue light was better than other colors lights, both at different photoperiods. The blue light and long light phase (24 light hours) produced the best fish percentage weight gain (WG $=1037.8 \%$ ), specific growth rate $(S G R=4.05 \%)$, daily growth rate $(D G R=17.3 \%)$ and growth efficiency $(G E=0.29)$. On the other hand, the blue light and light cycle 16L:8D gave weight gain $(W G=890.4 \%)$, specific growth rate $(S G R=3.82 \%)$, daily growth rate $(D G R=14.84 \%)$ and growth efficiency $(G E=0.27)$. The lowest mean values of feed conversation ratio $(F C R=1.04)$ was observed in blue light and long light photoperiod. The highest mean values of feed conversation ratio $(F C R=1.19)$ was observed in blue light and $16 \mathrm{~L}: 8 \mathrm{D}$ light cycle.
\end{abstract}

Keywords: photoperiod, light colors, fish performance.

\section{Introduction}

Spectral composition is a main characteristic of light. In water light rays of different wavelength pass to different depths depending on light absorption and diffusion as well as on availability of admixtures and small organisms in a water body. Most species of fish have well-developed color sight, and are therefore very sensitive to colored light. For instant, the survival rate of haddock larvae (Mellanogrammus aeglefinus L.) is higher with blu and green light (Downing 2002). The growth rate of silver carp larvae (Hypophthalmichthys molitrix Val.) and young carp (Cyprinus carpio L.) increased with green light (Radenk and Alimov 1991, Ruchin et al. 2002, Ruchin 2004).

The intensive culture of tilapia under controlled management systems is widely expanding to meet the increasing demands for these fishes, especially in developing countries. In this regard, the use of closed culture systems has received a considerable attention, and is becoming more common worldwide, particularly in arid areas that face shortage in fresh water or brackish water, or in areas where environmental parameters, such as salinity and temperature, are outside the tolerance range of tilapia (Muir et al., 2000; ElSayed and Kawanna, 2004).

Photoperiod acts as an artificial Zeitgeber (cue or synchronizer), regulating the daily endogenous rhythms in fish and also affects fish growth, locomotor activity, metabolic rates, body pigmentation, sexual maturation and reproduction (Duston and Saunders, 1990; Gross et al., 1995; Silva-Garcia, 1996; Boeuf and Le Bail,1999; Trippel and Neil, 2002; Biswas and Takeuchi, 2002; Biswas et al., 2002; Biswas et al., 2005). On the other hand, the growth and metabolic rates of several other species were not significantly affected by photoperiods (Imsland et al., 1995; Hallaråker et al., 1995; Purchase et al., 2000). Meanwhile, photoperiod may positively affect larval stages, but not juvenile stages (Barlow et al., 1995).

Adaptations of fish to their natural environment may also influence their response to the farming environ- ment. As in nature, light intensity and background color can affect feed detection and feeding success of cultured fish, thus influencing fish growth and mortality. In general, the highest growth rates of fish larvae are achieved when light conditions and background color optimize the contrast between the feed and the background (Barahona-Fernandes, 1979; Hinshaw,1986; Henne and Watanabe, 2003; Jentoft et al., 2006; Strand et al., 2007). Light intensity may also affect the size of prey preferred by juvenile fish (Mills et al., 1986). Tank colour has been shown to influence the success of larval swim bladder inflation (MartinRobichaud and Peter- son, 1998).

In most studies fluorescent lamps are used, resulting in what humans perceive as white light, despite the fact that: (a) in natural fish habitat, wavelength of light penetrating water varies greatly, (b) fish vision and spectrum perception are strongly adapted to each species natural habitat and living ethology (Chinen et al., 2005; Kusmic and Gualtieri, 2000; Neumeyer, 1992; Pointer et al., 2005), and (c) recent studies indicate that light spectrum affects farmed fish growth performance (Head and Malison, 2000; Karakatsouli et al., 2007, 
2008), behavior (Marchesan et al., 2005; Volpato et al., 2004) and physiological status (Head and Malison, 2000; Karakatsouli et al., 2007, 2008; Karakatsouli et al. 2010).

The objectives of the present study were to examine the effects of photoperiod and light color on growth rate and activity of Nil Tilapia (Tilapia Niloticus)

\section{Materials and Methods}

The experiments were carried out through the period $1^{\text {st }}$ October, 2012 to $1^{\text {st }}$ December, 2012. The experiments were studied 70 Nile tilapia fingerlings with initial weight $0.5 \mathrm{~g}$ in glass tanks at Kom Elflos fish farm $\left(31^{\circ} 06^{\prime} \mathrm{N}-30^{\circ} 56^{\prime} \mathrm{E}\right)$, Kfrelsheikh Governorate, Egypt. Experimental tanks (glass, length height width: $70 \mathrm{~cm} 50 \mathrm{~cm} 35 \mathrm{~cm}$, volume capacity 122.51 ), the tanks were provided with central drainage pipes surrounded by outer sleeves pipes, perforated at the bottom, to facilitate self-cleaning and waste removal. Continuous aeration through an air pump (Boyu, U -9900, $3.21 / \mathrm{mint}$ ) and heaters, with thermostats, to keep water temperature at $26^{\circ} \mathrm{C}$ (Fig. 1). About $20 \%$ of the water was replaced daily by new fresh water at the same temperature. Water quality parameters, including DO, ammonia and $\mathrm{pH}$ were recorded every ten days. The average values of these parameters throughout the study were: $\mathrm{DO}=6.5 \mathrm{mg} / \mathrm{l}$, ammonia $=0.049 \mathrm{mg} / \mathrm{l}$ and $\mathrm{pH}=7.9$.

The experiment was designed to study the effect of photoperiod and light color on Nile tilapia growth rates, feed utilization efficiency and survival of Nile tilapia. The fish were exposed to two photoperiod (light: dark, L: D) cycles (24L: 0D and 16L: 8D) by using fluorescent lamps and natural $1 \mathrm{ight}$-dark cycle (control, at experiment starting 11h 51mint L:12h 9mint D and experiment end 10h 21 mint L : 13h 39mint D). Light in each photoperiod tank was provided by two fluorescent lamps (36 W) suspended $100 \mathrm{~cm}$ above the water surface. On the other hand, the fish were exposed to three types of color light (whit, red and blue). Light intensity was measured every five days at water surface (at tank center) by a digital Lux Meter (Digital light meter Nicety LX-802) and was constant at around 600 lx throughout the experiment in artificial photoperiod groups.

Fish were acclimated to experimental tanks for 1 day under room ambient lighting. After the acclimation period white, red and blue light color and photoperiod were applied and fish remained in these conditions for 60 days. Light color was achieved by covering light source. The fish were fed by hand a commercial feed (crude protein, $27 \%$; crude lipid $5.06 \%$; crude fiber $5.08 \%$; total energy $4000 \mathrm{kcal} / \mathrm{kg}$ ) for 60 days. The diet was offered twice a day at 10:00 h and 16:00 h. Daily feeding rates (\% BW/day) were determined based on recommendations of different researchers (Morris and Mische, 1999; Al Hafedh, 1999; Coward and Bromage, 1999 and El-Sayed, 2002). Therefore, the daily rates were of $6 \%$ BW/day for 30 days and reduced to $5 \%$ BW/day for other 30 days. Fish were weighed at 10 days intervals (days: $0,10,20,30,40,50$ and 60) and feed intake were adjusted every 10 days also. Fish were weighed using an electronic balance (Shimadzu, EB$620 \mathrm{SU} \pm 0.01 \mathrm{~g}$ sensitivity). The data collected every ten days and the growth rates were measured in terms of specific growth rate (SGR), weight gain (WG), feed conversation ratio (FCR)and condition factor (K) as the following:



Fig. 1: experimental unit diagram. 


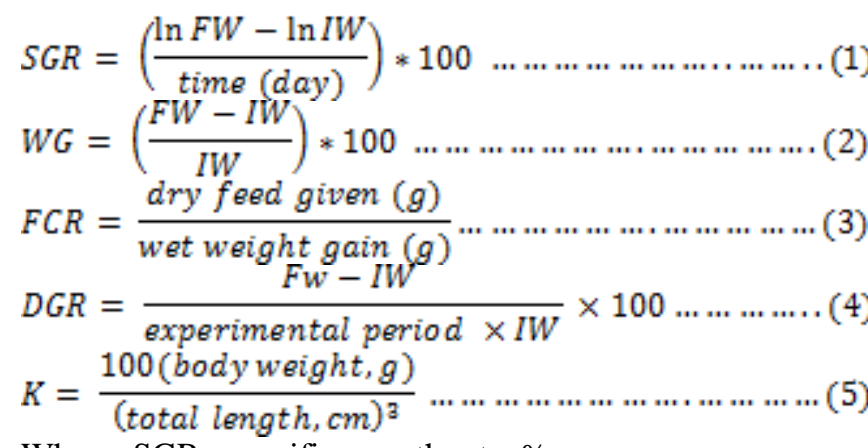

Where: $\mathrm{SGR}=$ specific growth rate, $\%$.

IW= initial weight, $g$.

$\mathrm{DGR}=$ daily growth rate, $\%$

$\mathrm{K}=$ condition factor.

To evaluate energy expenditure, the energetic growth efficiency (GE) was calculated, where GE is the ratio between the energy of the weight increase of the fish and the total energy intake of the fish (Larsson and Berglund, 2005):

$G E=\frac{U \times(F W-I W))}{(F I \times D E)}$.

where $\mathrm{J}$ is the conversion factor of mass to energy for percids $\left(5.0 \mathrm{~kJ} \mathrm{~g}^{-1}\right.$ wet weight) (calculated average from Hewet and Kraft, 1993 [P. flavescens] and Bryan et al., 1996 [P. flavescens and S. vitreum]), FW is the weight at time $\mathrm{t}(\mathrm{g})$, IW is the initial weight $(\mathrm{g})$, FI is the feed intake $(\mathrm{g})$, and DE is the digestible energy content of the feed $\left(16.747 \mathrm{~kJ} \cdot \mathrm{g}^{-1}\right.$, obtained from the manufacturer $)$.

The data obtained from the experiment were subjected to one-way analysis of variance (ANOVA) (using SPSS program) to test the effect of photoperiod and light color on the growth rates, feed utilization efficiency. When ANOVA identified significant difference among groups. Least significant difference (LSD) was used to compare means at $\mathrm{P}<0.05$.

\subsection{Effect of light period:}

\section{Results and discussion:}

Data and illustrations on growth patterns of Nile tilapia exposed to two long-day artificial photoperiod are presented in Tables 1 and 2 and Fig.2. The results of experiment indicated that photoperiod (24L:0D and 16L:8D) and ambient light regime (control) significantly affected fish growth performance (Table 1 and Fig. 2). The highest mean final weight $(48.62 \pm 0.30 \mathrm{~g})$ was reached in fish maintained under continuous light regime (24L:0D). Mean final weights of fish exposed to 16L:8D and control photoperiods were measured as $45.30 \pm$ 0.20 and $41.15 \pm 0.20 \mathrm{~g}$, respectively. At the end of experiment, there are significant differences between photoperiods $(\mathrm{p}<0.05)$. Significant differences in mean body weights of photoperiod groups and control were only detectable during the second month (days 30-60) of the experiment. Throughout this stage, mean body weight of fish at constant light regime (24L:0D) was significantly different and higher than that of other photoperiod regime $(16 \mathrm{~L}: 8 \mathrm{D})$ and control $(\mathrm{p}<0.05)$. Moreover, mean body weights of fish exposed to 16L:8D photoperiod groups were also found to be significantly different from that of control during this development stage (Table 1).

Table1: Effects of Photoperiod on Growth Rates

\begin{tabular}{|cccc|}
\hline \multirow{2}{*}{$\begin{array}{c}\text { Time } \\
\text { day) }\end{array}$} & \multicolumn{3}{c|}{ Mean body weight (g) } \\
\cline { 2 - 4 } & 24L:0D & 16L:8D & Control \\
\hline 0 (initial) & $5.00 \pm 0.02$ & $5.00 \pm 0.02$ & $5.00 \pm 0.02$ \\
$\mathbf{1 0}$ & $7.31 \pm 0.12^{\mathrm{a}}$ & $7.24 \pm 0.11^{\mathrm{a}}$ & $7.10 \pm 0.11^{\mathrm{a}}$ \\
$\mathbf{2 0}$ & $10.69 \pm 0.21^{\mathrm{a}}$ & $10.48 \pm 0.15^{\mathrm{a}}$ & $10.07 \pm 0.14^{\mathrm{a}}$ \\
$\mathbf{3 0}$ & $15.63 \pm 0.25^{\mathrm{a}}$ & $15.17 \pm 0.15^{\mathrm{a}}$ & $14.29 \pm 0.15^{\mathrm{b}}$ \\
$\mathbf{4 0}$ & $22.86 \pm 0.28^{\mathrm{a}}$ & $21.96 \pm 0.20^{\mathrm{a}}$ & $20.28 \pm 0.19^{\mathrm{b}}$ \\
$\mathbf{5 0}$ & $33.43 \pm 0.31^{\mathrm{a}}$ & $31.80 \pm 0.19^{\mathrm{b}}$ & $28.77 \pm 0.19^{\mathrm{c}}$ \\
$\mathbf{6 0}$ & $48.62 \pm 0.30^{\mathrm{a}}$ & $45.30 \pm 0.20^{\mathrm{b}}$ & $41.15 \pm 0.20^{\mathrm{c}}$ \\
\hline
\end{tabular}

$*$ Values in the same row with different superscripts are significantly different $(\mathrm{P}<0.05)$ from each other. 
The results indicated that photoperiod significantly affected fish growth performance (Table 2). The long light phase (24 light hours) produced the best fish percentage weight gain( $\mathrm{WG}=872.4 \%$ ), specific growth rate $(\mathrm{SGR}=3.79 \%)$, daily growth rate $(\mathrm{DGR}=14.54 \%)$ and growth efficiency $(\mathrm{GE}=0.26)$. The control treatment produced the lowest values of weight gain $(\mathrm{WG}=723 \%)$, specific growth rate $(\mathrm{SGR}=3.51$ $\%)$, daily growth rate $(\mathrm{DGR}=12.05 \%)$ and growth efficiency $(\mathrm{GE}=0.24)$. The lowest mean values of feed conversation ratio $(F C R=1.14)$ and condition factor $(K=2.21)$ were observed in long light photoperiod. The highest mean values of feed conversation ratio $(F C R=1.24)$ and condition factor $(K=2.38)$ were observed in control.

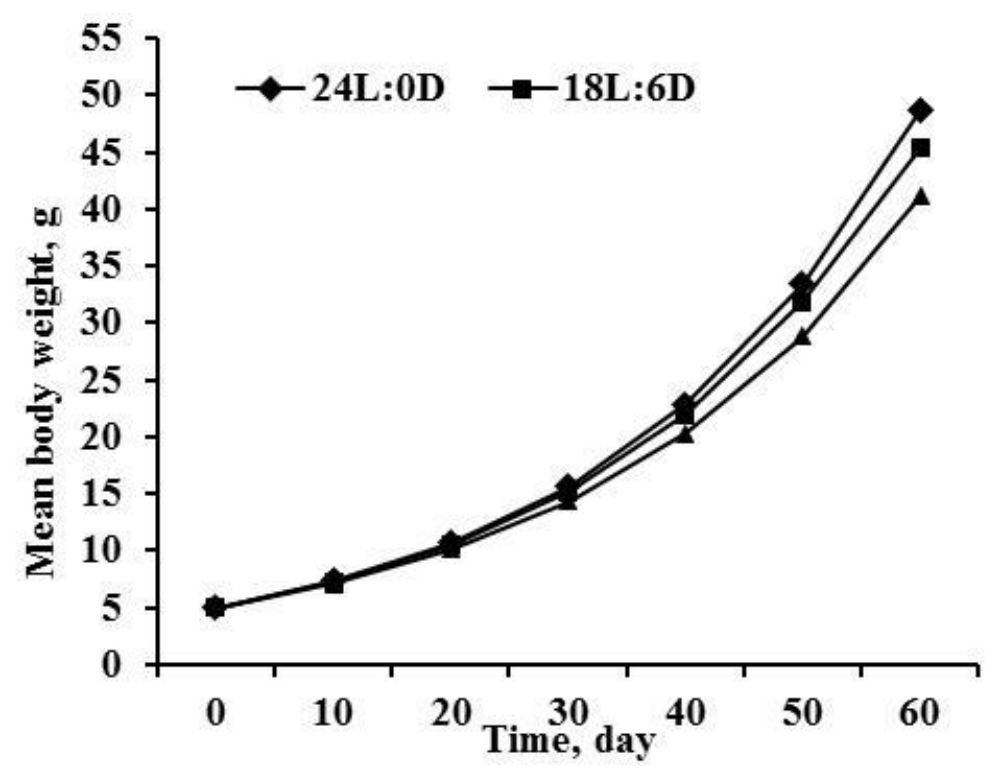

Fig. 2. Effect of photoperiod regimes on the growth performance of Nile tilapia.

The present study demonstrated that the growth and feed efficiency of Nile tilapia were significantly affected by photoperiod. Mean final weights and growth performance (SGR, WG, DGR and GE) of fish exposed to different artificial photoperiods and ambient natural light cycle in this study (Tables 2) reveal that growth in Nile Tilapia is enhanced under constant long-day artificial photoperiods (24L:0D and 16L:8D) when compared to natural light regime. Long-day photoperiods have been reported to stimulate growth in a number of fish species (Boeuf and Le Bail, 1999; Randall et al., 2001). Biswas and Takeuchi, 2003; Biswas andTakeuchi, 2002 and Biswas et al., 2002) have similarly reported clear effect of photoperiod manipulation on growth in Nile tilapia.

The improvement in the performance of Nile tilapia the present study with increasing light period may also have been related to the reduction of standard metabolic rate. In support, Biswas et al. (2002) and Biswas and Takeuchi (2002) studied the effects of photoperiod on the metabolic rate of fed and unfed young and adult Nile tilapia. They found that metabolic rate and energy loss were negatively correlated with light periods. They concluded that Nile tilapia conserve energy when raised under photoperiods with longerlight phases. However, these authors suggested that growth studies must be conducted under different photoperiod cycles in order to further evaluate the effects of photoperiod regimes on these fish. The reduction of fish metabolic rate with increasing light phases has also been reported with marine fish species (Boehlert, 1981).

Table: 2. Effects of Photoperiod on Nile Tilapia Growth Parameters (mean \pm SD)

\begin{tabular}{|c|c|c|c|}
\hline \multirow{2}{*}{ Parameter } & \multicolumn{3}{|c|}{ L : D cycle } \\
\hline & 24L:0D & 16L:8D & Control \\
\hline Initial weight (IW), g & $5.00 \pm 0.02$ & $5.00 \pm 0.02$ & $5.00 \pm 0.02$ \\
\hline Final weight (FW), g & $48.62 \pm 0.30^{\mathrm{a}}$ & $45.30 \pm 0.20^{b}$ & $41.15 \pm 0.20^{\mathrm{c}}$ \\
\hline Weight gain (WG), \% & $872.4 \pm 6.1^{\mathrm{a}}$ & $806 \pm 4^{\mathrm{a}}$ & $723 \pm 4^{\mathrm{b}}$ \\
\hline Specific growth rate (SGR), \% & $3.79 \pm 0.01^{\mathrm{a}}$ & $3.67 \pm 0.01^{\mathrm{b}}$ & $3.51 \pm 0.01^{\mathrm{c}}$ \\
\hline Daily growth rate (DGR), & $14.54 \pm 0.1^{\mathrm{a}}$ & $13.43 \pm 0.07^{\mathrm{b}}$ & $12.05 \pm 0.07^{\mathrm{c}}$ \\
\hline Feed conversation ratio (FCR) & $1.14 \pm 0.01^{\mathrm{a}}$ & $1.19 \pm 0.01^{\mathrm{a}}$ & $1.24 \pm 0.01^{\mathrm{b}}$ \\
\hline Condition factor $(\mathbf{K})$ & $2.21 \pm 0.02^{\mathrm{a}}$ & $2.32 \pm 0.01^{\mathrm{a}}$ & $2.38 \pm 0.01^{\mathrm{a}}$ \\
\hline Growth efficiency (GE) & $0.26 \pm 0.01^{\mathrm{a}}$ & $0.25 \pm 0.01^{\mathrm{ab}}$ & $0.24 \pm 0.01^{\mathrm{b}}$ \\
\hline
\end{tabular}

$*$ Values in the same row with different superscripts are significantly different $(\mathrm{P}<0.05)$ from each other. 


\subsection{Effect of color light:}

Data and illustrations on growth patterns of Nile tilapia exposed to three types of light colorsand two long-day artificial photoperiod are presented in Tables 3 and 4 and Fig. 3and 4. The results of experiment indicated that light colors (whit, red and blue) significantly affected fish growth performance (Table 3 and Fig. 4). The highest mean final weight $(56.89 \pm 0.4 \mathrm{~g})$ was reached in fish maintained under blue lightand continuous light regime (24L:0D). while the mean final weight for fish exposed to blue light and 16L:8D was $49.52 \pm 0.4 \mathrm{~g}$. Mean final weights of fish exposed to white and red light under $24 \mathrm{~L}: 0 \mathrm{D}$ cycle were $48.62 \pm 0.3 \mathrm{~g}$ and $51.81 \pm 0.5 \mathrm{~g}$ respectively. On the other hand, the mean final weight of fish exposed to white and red light under 16L:8D cycle were $45.3 \pm 0.2 \mathrm{~g}$ and $47.89 \pm 0.4 \mathrm{~g}$ respectively. There are significant differences between light colors $(\mathrm{p}<0.05)$. Throughout this experiment, mean body weight of fish at blue light was significantly different and higher than that of other light colors $(\mathrm{p}<0.05)$ both at two photoperiods (Table 3$)$.

Table3: Effects of Light Color on Growth Rates

\begin{tabular}{|c|l|l|l|l|l|l|}
\hline \multirow{2}{*}{$\begin{array}{c}\text { Time } \\
\text { day) }\end{array}$} & \multicolumn{5}{|c|}{ Mean body weight (g) } \\
\cline { 2 - 7 } & \multicolumn{2}{|c|}{ 24L:0D } & \multicolumn{3}{c|}{$\mathbf{1 6 L : 8 D}$} \\
\cline { 2 - 7 } & white & red & blue & white & red & blue \\
\hline 0(initial) & 5.00 & 5.00 & 5.00 & 5.00 & 5.00 & 5.00 \\
\hline $\mathbf{1 0}$ & 7.31 & 7.38 & 7.50 & 7.24 & 7.29 & 7.33 \\
\hline $\mathbf{2 0}$ & 10.69 & 10.91 & 11.24 & 10.48 & 10.63 & 10.73 \\
\hline $\mathbf{3 0}$ & 15.63 & 16.11 & 16.85 & 15.17 & 15.49 & 15.73 \\
\hline $\mathbf{4 0}$ & 22.86 & 23.79 & 25.27 & 21.96 & 22.59 & 23.04 \\
\hline $\mathbf{5 0}$ & 33.43 & 35.14 & 37.90 & 31.80 & 32.93 & 33.77 \\
\hline $\mathbf{6 0}$ & 48.62 & 51.81 & 56.89 & 45.30 & 47.89 & 49.52 \\
\hline
\end{tabular}

The results indicated that light colors significantly affected fish growth performance (Table 4). The blue light was better than other colors lights, both at different photoperiods. The blue light and long light phase (24 light hours) produced the best fish percentage weight gain $(\mathrm{WG}=1037.8 \%)$, specific growth rate $(\mathrm{SGR}=$ $4.05 \%)$, daily growth rate $(\mathrm{DGR}=17.3 \%)$ and growth efficiency $(\mathrm{GE}=0.29)$. On the other hand, the blue light and light cycle 16L:8D gave weight gain $(\mathrm{WG}=890.4 \%)$, specific growth rate $(\mathrm{SGR}=3.82 \%)$, daily growth rate $(\mathrm{DGR}=14.84 \%)$ and growth efficiency $(\mathrm{GE}=0.27)$. The lowest mean values of feed conversation ratio $($ FCR $=1.04)$ was observed in blue light and long light photoperiod. The highest mean values of feed conversation ratio $(\mathrm{FCR}=1.19)$ was observed inblue light and $16 \mathrm{~L}: 8 \mathrm{D}$ light cycle.
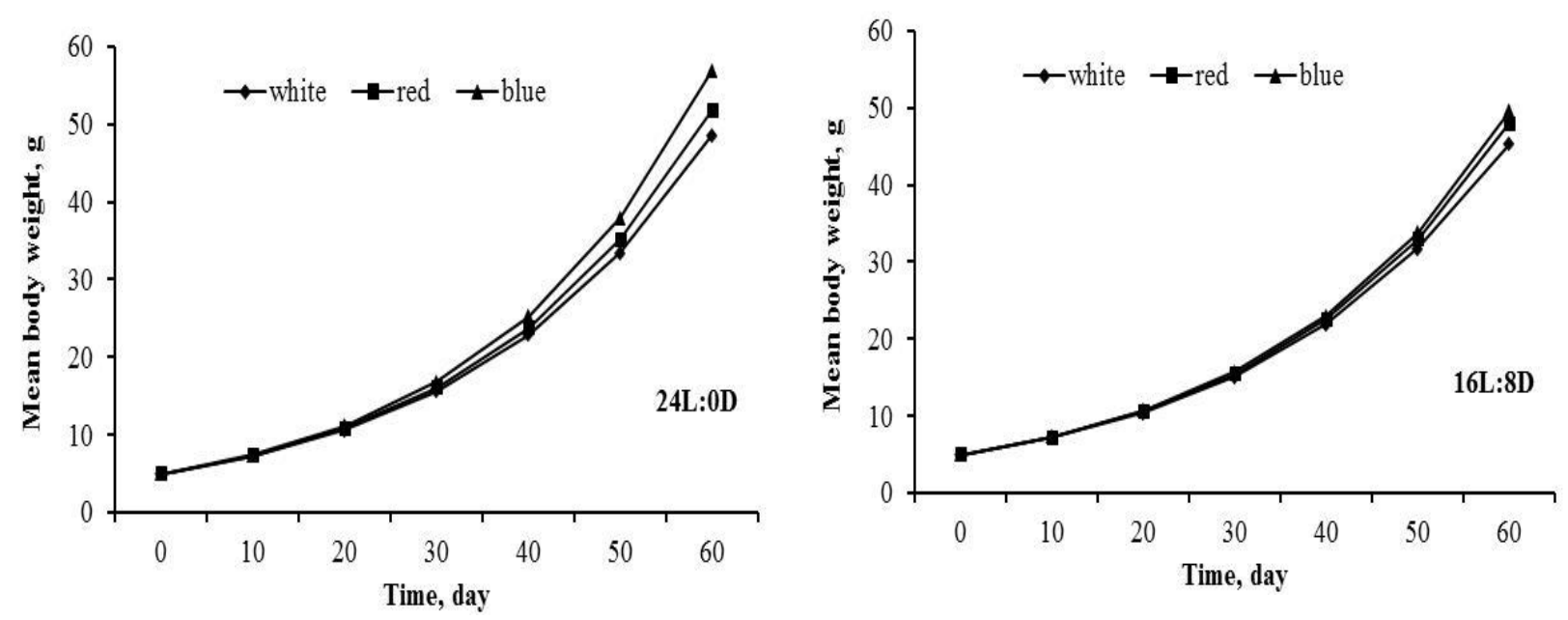

Fig. 3. Effect of light color on the growth performance of Nile tilapia. 


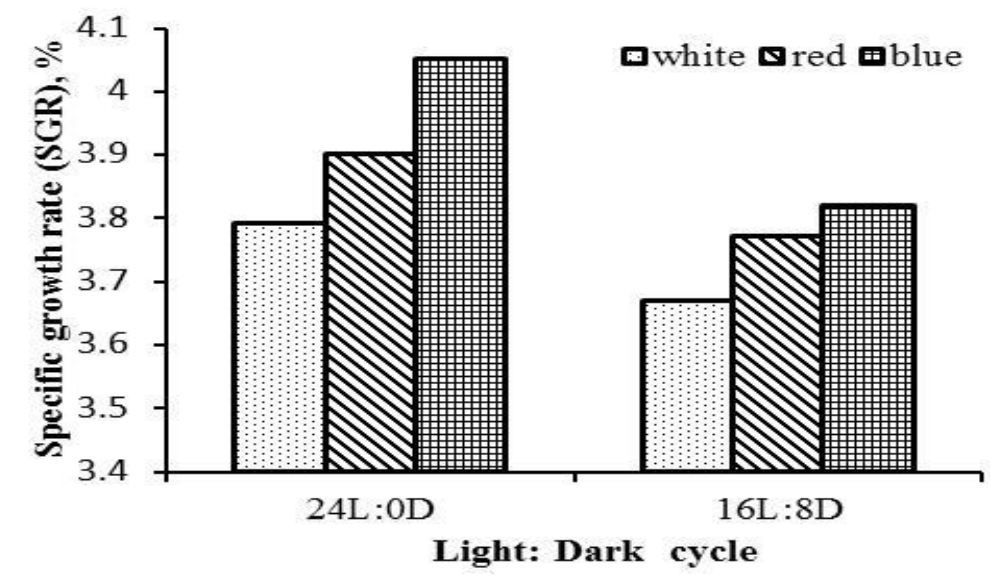

Fig. 4. Effect of light color on specific growth rate of Nile tilapia.

The present study demonstrated that the growth and feed efficiency of Nile tilapia were significantly affected by light colors. Mean final weights and growth performance (SGR, WG, DGR and GE) of fish exposed to different light colors in this study (Tables 4) reveal that growth in Nile Tilapia is enhanced under blue light when compared to white and red lights. Light colors have been reported to stimulate growth in a number of fish species (Ruchin, 2004; Marchesan et al., 2005; Strand et al., 2007 and Luchiari and Freire, 2009).

Table: 4. Effects of Photoperiod and Light Color on Nile Tilapia Growth Parameters (mean \pm SD)

\begin{tabular}{|c|c|c|c|c|}
\hline \multirow{2}{*}{$\begin{array}{l}\text { Light: Dark } \\
\text { cycle }\end{array}$} & \multirow{2}{*}{ Parameters } & \multicolumn{3}{|c|}{ Light color } \\
\hline & & White & Red & Blue \\
\hline \multirow{8}{*}{ 24L:0D } & Initial weight (IW), g & $5.00 \pm 0.02$ & $5.00 \pm 0.02$ & $5.00 \pm 0.02$ \\
\hline & Final weight $(\mathrm{FW}), \mathrm{g}$ & $48.62 \pm 0.3^{\mathrm{a}}$ & $51.81 \pm 0.5^{\mathrm{b}}$ & $56.89 \pm 0.4^{\mathrm{c}}$ \\
\hline & Weight gain (WG), \% & $872.4 \pm 6.1^{\mathrm{a}}$ & $936.2 \pm 10^{\mathrm{b}}$ & $1037.8 \pm 8^{\mathrm{c}}$ \\
\hline & Specific growth rate (SGR), \% & $3.79 \pm 0.01^{\mathrm{a}}$ & $3.9 \pm 0.01^{\mathrm{ab}}$ & $4.05 \pm 0.01^{b}$ \\
\hline & Daily growth rate (DGR), & $14.54 \pm 0.1^{\mathrm{a}}$ & $15.6 \pm 0.16^{\mathrm{ab}}$ & $17.3 \pm 0.1^{b}$ \\
\hline & Feed conversation ratio (FCR) & $1.14 \pm 0.01^{\mathrm{a}}$ & $1.1 \pm 0.01^{\mathrm{b}}$ & $1.04 \pm 0.01^{\mathrm{b}}$ \\
\hline & Condition factor $(\mathbf{K})$ & $2.21 \pm 0.02^{\mathrm{a}}$ & $2.25 \pm 0.02^{\mathrm{a}}$ & $2.3 \pm 0.02^{\mathrm{a}}$ \\
\hline & Growth efficiency (GE) & $0.26 \pm 0.01^{\mathrm{a}}$ & $0.27 \pm 0.01^{\mathrm{ab}}$ & $0.29 \pm 0.01^{b}$ \\
\hline \multirow{8}{*}{ 16L:8D } & Initial weight (IW), g & $5.00 \pm 0.02$ & $5.00 \pm 0.02$ & $5.00 \pm 0.02$ \\
\hline & Final weight $(\mathrm{FW}), \mathrm{g}$ & $45.3 \pm 0.2^{\mathrm{a}}$ & $47.89 \pm 0.4^{b}$ & $49.52 \pm 0.4^{b}$ \\
\hline & Weight gain (WG), \% & $806 \pm 4^{a}$ & $857.8 \pm 8^{\mathrm{b}}$ & $890.4 \pm 8^{b}$ \\
\hline & Specific growth rate (SGR), \% & $3.67 \pm 0.01^{\mathrm{a}}$ & $3.77 \pm 0.01^{\mathrm{a}}$ & $3.82 \pm 0.01^{\mathrm{a}}$ \\
\hline & Daily growth rate (DGR), & $13.43 \pm 0.07^{\mathrm{a}}$ & $14.3 \pm 0.13^{\mathrm{ab}}$ & $14.84 \pm 0.13^{b}$ \\
\hline & Feed conversation ratio $($ FCR $)$ & $1.19 \pm 0.01^{\mathrm{a}}$ & $1.15 \pm 0.01^{b}$ & $1.13 \pm 0.01^{\mathrm{b}}$ \\
\hline & Condition factor $(\mathbf{K})$ & $2.32 \pm 0.01^{\mathrm{a}}$ & $2.28 \pm 0.02^{\mathrm{a}}$ & $2.25 \pm 0.02^{\mathrm{a}}$ \\
\hline & Growth efficiency (GE) & $0.25 \pm 0.01^{\mathrm{a}}$ & $0.26 \pm 0.01^{\mathrm{ab}}$ & $0.27 \pm 0.02^{b}$ \\
\hline
\end{tabular}

*Values in the same row with different superscripts are significantly different $(\mathrm{P}<0.05)$ from each other.

It has been suggested that freshwater fish species are more sensitive to photoperiod than marine and diadromous species (Imsland et al., 1995). However, the response of marine species to photoperiods has been well investigated, while less information is available on freshwater species.

In conclusion, the present results revealed that photoperiods and color light were significantly affect the growth of Nile tilapia. A 24L:0D cycle and blue light were suggested for optimal performance of fish. These results have a significant application in tilapia aquaculture in indoor recirculating systems, as they improve our understanding of the role that photoperiod and light color plays in fish growth and metabolism. Adopting the optimum photoperiod in case of tilapia will also reduce the amount of energy used for standard metabolism, and in turn increase fish growth and profitability (El-Sayed and Kawanna, 2004).

\section{References:}

[1] Al Hafedh, Y.S., 1999. Effects of dietary protein on growth and body composition of Nile tilapia, Oreochromisniloticus L. Aquaculture Research 30, 385-393.

[2] Barahona-Fernandes, M.H., 1979. Some effects of light intensity and photoperiod on the sea bass larvae _Dicentrarchuslabrax. reared at the Centre Oce'anologique de Bretagne. Aquaculture 17, 311-321. 
[3] Barlow, C.G., Pearce, M.G., Rodgers, L.J., Clayton, P., 1995. Effects of photoperiod on growth, survival, and feeding periodicity of larval and juvenile barramundi, Latescalcarifer (Bloch). Aquaculture 138, 159- 168.

[4] Biswas, A.K., Endo, M., Takeuchi, T., 2002. Effects of different photoperiod cycles on metabolic rate and energy loss of both fed and unfed young tilapia Orochromisniloticus: part I. Fisheries Science 68, 465-477.

[5] Biswas, A.K., Morita, T., Yoshizaki, G., Maita, M., Takeuchi, T., 2005. Control of reproduction in Nile tilapia Oreochromisniloticus (L.) by photoperiod manipulation. Aquaculture 243, 229-239.

[6] Biswas, A.K., Takeuchi, T., 2002. Effects of different photoperiod cycles on metabolic rate and energy loss of both fed and unfed adult tilapia Orochromisniloticus: part II. Fisheries Science 68, 543-553.

[7] Biswas, A.K., Takeuchi, T., 2003. Effects of photoperiod and feeding interval on food intake and growth of Nile tilapia Orochromisniloticus L. Fisheries Science 69, 1010-1016.

[8] Boehlert, G.W., 1981. The effects of photoperiod and temperature on laboratory growth of juvenile Sebastesdiploproaand a comparison with growth in the field. Fish. Bull. 79, 789- 794.

[9] Boeuf, G.; Le Bail, P.-Y., 1999: Does light have an influence on fish growth? Aquaculture 177, 129-152.

[10] Bryan, S.D., Souprir, C.A., Duffy, W.G., Freiburger, C.E., 1996. Caloric densities of three predatory fishes and their prey in lake Oahe, South Dakota. J. Freshw. Ecol. 11, 153-161.

[11] Chinen, A., Matsumoto, Y., Kawamura, S., 2005. Spectral differentiation of blue opsins between phylogenetically close but ecologically distant goldfish andnzebra fish. J. Biol. Chem. 280, 9460-9466.

[12] Coward, K., Bromage, N.R., 1999. Spawning frequency, fecundity, egg size and ovarian histology in groups of Tilapia zilli maintained upon two distinct food ration sizes from first-feeding to sexual maturity. Aquatic Living Resources 12, 11-22.

[13] Cowing, J.A., Hunt, D.M., 2005. Adaptations to an extreme environment: retinal organisation and spectral properties of photoreceptors in Antarctic notothenioid fish. J. Exp. Biol. 208, 2363-2376.

[14] Downing, G., 2002. Impact of spectral composition on larval haddock, Melanogrammusaeglefinus L., growth and survival. Aquacult. Res. 33, 251-259.

[15] Duston, J., Saunders, R.L., 1990. The entrainment role of photoperiod on hypoosmoregulatory and growthrelated aspects of smolting in Atlantic salmon (Salmosalar). Can. J. Zool. 68, 707-715.

[16] El-Sayed, A.F., Kawanna, M., 2004. Effects of photoperiod on the performance of farmed Nile tilapia Oreochromisniloticus: I. Growth, feed utilization efficiency and survival of fry and fingerlings. Aquaculture 231, 393-402.

[17] El-Sayed, A.M., 2002. Effects of stocking density and feeding levels on growth and feed efficiency of Nile tilapia (Oreochromisniloticus L.). Aquaculture Research 33, 621-626.

[18] Gross, W.L., Roelofs, E.W., Fromm, P.O., 1995. Influence of photoperiod on growth of green sunfish, Lepomiscyanellus. J. Fish. Res. Board Can. 22, 1379- 1386

[19] Hallara ${ }^{\circ}$ ker, H., Folkvord, A., Stefansson, S.O., 1995. Growth of juvenile halibut (Hippoglossushippoglossus) related to temperature, day length and feeding regime. Neth. J. Sea Res. 34, 139- 147.

[20] Head, A.B.,Malison, J.A., 2000. Effects of lighting spectrum and disturbance level on the growth and stress responses of yellow perch Percaflavescens. J. World Aquacult. Soc. 31, 73-80.

[21] Henne, J.P., Watanabe, W.O., 2003. Effects of light intensity and salinity on growth, survival, and whole-body osmolality of larval southern flounder Paralichthyslethostigma. J.WorldAquac. Soc. 34, 450-465.

[22] Hewet, S.W., Kraft, C.E., 1993. The relationship between growth and consumption: comparisons across fish populations. Trans. Am. Fish. Soc. 122, 814-821.

[23] Hinshaw, J.M., 1986. Factors Affecting Feeding, Survival, and Growth of Larval and Early Juvenile Yellow Perch (Percaflavescens, Mitchill). Diss. Abstr. Int., B. Sci. Eng., vol. 47. North Carolina State University, Raleigh, USA. 93 pp.

[24] Imsland, A., Folkvord, A.F., Stefansson, S.O., 1995. Growth, oxygen consumption and activity of juvenile turbot ScophthalmusmaximusL..reared under different temperatures and photoperiods. Netherlands J. Sea Res. 34, 149-159.

[25] Jentoft, S., Oxnevad, S., Aastveit, A.H., Andersen, O., 2006. Effects of tank wall color and up-welling water flow on growth and survival of Eurasian perch larvae (Percafluviatilis). J. World Aquac. Soc. 37, 313-317.

[26] Karakatsouli, N., Papoutsoglou, S.E., Panopoulos, G., Papoutsoglou, E.S., Chadio, S., Kalogiannis, D., 2008. Effects of light spectrum on growth and stress response of rainbow trout Oncorhynchusmykiss reared under recirculating system conditions. Aquacult. Eng. 38, 36-42.

[27] Karakatsouli, N., Papoutsoglou, S.E., Pizzonia, G., Tsatsos, G., Tsopelakos, A., Chadio, S., Kalogiannis, D., Dalla, C., Polissidis, A., Papadopoulou-Daifoti, Z., 2007. Effects of light spectrum on growth and physiological status of gilthead seabreamSparusaurata and rainbow trout Oncorhynchusmykiss reared under recirculating system conditions. Aquacult. Eng. 36, 302-309.

[28] Karakatsouli,N., Papoutsoglou,S.E., Sotiropoulos, N, Stigen-Martinsen,T.D.N., Sofronios E. Papoutsoglou, E. S., 2010. Effects of light spectrum, rearing density and light intensity on growth performance of scaled and mirror common carp Cyprinuscarpio reared under recirculating system conditions. Aquacultural Engineering 42 (2010) 121-127.

[29] Kusmic, C., Gualtieri, P., 2000. Morphology and spectral sensitivities of retinal and extraretinal photoreceptors in freshwater teleosts. Micron 31, 183-200.

[30] Larsson, S., Berglund, I., 2005. The effect of temperature on the energetic growth efficiency of Arctic charr (Salvelinusalpinus L.) from four Swedish populations. J. Therm. Biol. 30, 29-36.

[31] Luchiari, A.C., Freire, F.A.M., 2009. Effects of environmental colour on growth of Nile tilapia, Oreochromisniloticus (Linnaeus, 1758), maintained individually or in groups. J. Appl. Ichthyol. 25, 162-167.

[32] Marchesan, M., Spoto, M., Verginella, L., Ferrero, E.A., 2005. Behavioural effects of artificial light on fish species of commercial interest. Fish Res. 73, 171-185.

[33] Martin-Robichaud, D.J., Peterson, R.H., 1998. Effects of light intensity, tank colour and photoperiod on swimbladder inflation success in larval striped bass, Moronesaxatilis (Walbaum). Aquac. Res. 29, 539-547.

[34] Mills, E.L., Confer, J.L., Kretchmer, D.W., 1986. Zooplankton selection by young yellow perch: the influence of light, prey density, and predator size. Trans. Am. Fish. Soc. 115, 716-725.

[35] Morris, J.E., Mische, C.C., 1999. Tilapia Culture in Iowa. Iowa State University, University Extension, USA.

[36] Muir, J., Van Rijn, J., Hargreaves, J., 2000. Production in intensive and recycle systems. In: Beveridge, M.C.M., McAndrew, B.J. (Eds.), Tilapias: Biology and Exploitation. Kluwer Academic Publishing, Great Britain, pp. 405- 445.

[37] Neumeyer, C., 1992. Tetrachromatic color vision in goldfish: evidence from color mixture experiments. J. Comp. Physiol. A 171, 639-649.

[38] Papoutsoglou, S.E., Karakatsouli, N., Louizos, Chadio, S., Kalogiannis, D., Dalla, C., Polissidis, A., Papadopoulou-Daifoti, Z., 2007. Effect of Mozart's music (Romanze-Andante of "EineKleineNachtMusik", sol major, K525) stimulus on common carp (Cyprinuscarpio L.) physiology under different light conditions. Aquacult. Eng. 36, 61-72. 
[39] Pointer, M.A., Cheng, C.-H.C., Bowmaker, J.K., Parry, J.W.L., Soto, N., Jeffery, G., Purchase, C.F., Boyce, D.L., Brown, J.A., 2000. Growth and survival of juvenile yellowtail flounder (PleuronectesferrugineusStorer) under different photoperiods. Aquaculture Research 31, 547-552.

[40] Radenko, V. N.; Alimov, I. A., 1991: Importance of temperature and light to growth and survival of larval silver carp, Hypophthalmichthysmolitrix. Vopr. Ikhtiol. 31, 655-663.

[41] Randall, C., North, B., Futter, W., Porter, M., Bromage, N., 2001. Photoperiod effects on reproduction and growth in rainbow trout. Trout News 32, 12-16.

[42] Ruchin, A. B., 2004: Influence of coloured light on growth rate of juveniles of fish. Fish Physiol. Biochem. 30, 175-178.

[43] Ruchin, A. B.; Vechkanov, V. S.; Kuznetsov, V. A., 2002: Growth and feeding intensity of young carp Cyprinuscarpio under different constant and variable monochromatic illuminations. J. Ichthyol. 42, 191-199.

[44] Silva-Garcia, A.J., 1996. Growth of juvenile gilthead seabream _SparusaurataL..reared under different photoperiod regimes. Israeli J. Aquacult., Bamidgeh 48, 84-93.

[45] Strand, A.,Magnhagen, C., Alanärä, A., 2007. Effects of repeated disturbances on feed intake, growth rates and energy expenditures of juvenile perch, Percafluviatilis. Aquaculture 265, 163-168.

[46] Trippel, E.A., Neil, S.R.E., 2002. Effect of photoperiod and light intensity on growth and activity of juvenile haddock (Melanogrammusaeglefinus). Aquaculture 217, 633-645.

[47] Volpato, G.L., Duarte, C.R.A., Luchiari, A.C., 2004. Environmental color affect Nile tilapia reproduction. Braz. J. Med. Biol. Res. $37,479-483$. 